\title{
EFFECT OF PLANT DENSITY ON THE GROWTH, DEVELOPMENT AND YIELD OF BRUSSELS SPROUTS (Brassica oleracea L. var. gemmifera L.)
}

\author{
Victor Alekseevich Turbin ${ }^{1}$, Artem Siergiejevicz Sokolov ${ }^{1}$, Edyta Kosterna ${ }^{2 *}$, Robert Rosa $^{2}$ \\ ${ }^{1}$ Southern Branch of the National University of Life and Environmental Sciences of Ukraine Crimean Agrotechnological University \\ 95492 Simferopol, Agrarnoe, Ukraine \\ ${ }^{2}$ Faculty of Agriculture, Siedlce University of Natural Sciences and Humanities \\ Prusa 14, 08-110 Siedlce, Poland \\ * e-mail: warzywa@uph.edu.pl
}

Received: 15.07.2013

\begin{abstract}
Plant density is an important variable for achieving maximum yields and uniform vegetable maturity. Optimal plant density can be achieved by establishing appropriate distances both between the rows as well as in the rows of plants. The experiment was carried out between 2010-2012 at the experimental field of the Crimean Agrotechnological University in Simferopol, Ukraine. The experiment was established as randomised blocks with four replications. This study aimed to determine the effect of plant density on the growth, development and yield of Brussels sprouts. Increasing the area per plant resulted in a shortening of the time to the beginning of head formation, technical maturity and harvest. In all study years, increasing the distance between plants caused an increase in leaf assimilation area, stalk diameter and the number of heads per plant, however, the height of plants was lower. The most favourable parameters characterising marketable yield were found at an area per plant of $0.56 \mathrm{~m}^{2}$, however, the maximum yield from 1 ha (determining the profitability of the cultivation) was found at an area of $0.49 \mathrm{~m}^{2}$ per plant.
\end{abstract}

Key words: Brassica oleracea L. var. gemmifera L., biometric parameters, leaf assimilation area, spacing, marketable yield, quality of marketable heads

\section{INTRODUCTION}

Brussels sprouts (Brassica oleracea L. var. gemmifera L.) is a member of Brassicaceae family and researches on Brussels sprouts became dense on their cancer preventive effects, sowing and planting time, plant density, fertilizing, timing, stopping and relations between temperature and plant development [1].

Plant density is an important variable for achieving maximum yields and uniform vegetable ma- turity. Differentiation of density of plants per unit of area gives possibility of regulation of the size of edible part of such vegetables as e.g. cauliflower [2], broccoli [3-4], kohlrabi [5] or lettuce [6]. Optimal plant density can be achieved by establishing appropriate distances both between the rows as well as in the rows of plants [7-9]. Recommended spacing of Brussels sprouts depending on the date of cultivation and cultivar amounted to $50-70 \mathrm{~cm}$ between the rows and $50-60 \mathrm{~cm}$ in row, what responding cultivation area per plant from 0.25 to $0.42 \mathrm{~m}^{2}$ [10-11]. The effect of density on the yield and its quality in Brussels sprouts cultivation was investigated by $\mathrm{Abuzeid}$ and $\mathrm{Wilcock}$ son [12], B ortness [13], Everaarts and De Mo e 1 [14] and cabbage vegetables for early harvest by Lan Chow Wing and Rajkomar [15]. In the study by Whitwell et al. [16] was found that increase plant density caused increase yield of small heads and decrease yield of heads at diameter above $30 \mathrm{~mm}$. However, plants density did not influence on the marketable yield level. Similar influence of Brussels sprouts density on the share of small heads in the marketable yield was achieved by Everaarts and De Moel [14]. A decrease in yield with an increase in plant density from 2.7 to 4.4 plants per $1 \mathrm{~m}^{2}$ authors were found in only one year. In turn, A b u z e id and $\mathrm{W}$ il c o ck s on [12] reported that low planting densities gave high yields of small buds at early harvests but denser planting gave higher yields at later harvests. However, B ortn e s s [13] was found that plant density had no significant effect on the yield of Class 1 sprouts, but a low density increased the sprout size. Studies involving broccoli, cauliflower [2] and head cabbage [17], demonstrated that increased plant densi- 
ty via a reduction in the distance between plants in rows can cause an increase in yield. But I s l a m et al. [18] and Farooque and Islam [19] reported that the yield of cabbage cultivated at a spacing of $60 \times 30 \mathrm{~cm}$ and $60 \times 45 \mathrm{~cm}$ did not differ significantly. However, Moniruzzaman [20] was found that with an increase of cabbage spacing increase mass of heads but decrease marketable yield.

Plant density also influences biometric parameters of cultivated plants and consequently, the quality of edible parts. Within the range of 0.15 to $0.45 \mathrm{~m}^{2}$ area per plant, which covers the range of commercial densities, no effect of plant density on bud initiation in Brussels sprouts, leaf area index (LAI) and stem length is observed [12, 21].In turn, in the study by $\mathrm{S}$ a r k e $\mathrm{r}$ et al. [22] plant spacing had marked influence on the growth parameters like number of leaves per plant and diameter of head. Decreased plants density caused increase of investigated parameters, but had no influence on a plant height. In the study by $\mathrm{N}$ we ke et al. [23] decrease spacing of cucumber from $50 \times 50$ to $50 \times 30$ contributed to an increase the number and area of leaves and also increased almost 2 times the number of fruits.

This study aimed to determine the effect of plant density on the growth, development phenology and biometric parameters of Brussels sprouts plants and yields.

\section{MATERIALS AND METHODS}

The experiment was carried out in the years 2010-2012 at the experimental field of the Crimean Agrotechnological University in Simferopol, Ukraine, in the tectonic foreland zone of the Crimean Peninsula $\left(44^{\circ} 56^{\prime} \mathrm{N}, 34^{\circ} 06^{\prime} \mathrm{E}\right)$. A field experiment was established on steppe black soil formed on carbonate. The soil organic matter content ranged from 2.0 to $2.9 \%$ and its humus horizon reached a depth of $60-70 \mathrm{~cm}$. The soil reaction was slightly alkaline. The total content of nitrogen ranged from 2.75 to $7.02 \mathrm{~g}$, phosphorus from 2.25 to 3.25 , and potassium from 25.03 to $45.01 \mathrm{~g} \times \mathrm{dm}^{-3}$ of soil. Seeds of Brussels sprouts 'Franklin $F_{1}$ ' were obtained from the Dutch seed company Bejo Zaden. According to the producer the earliest yield of heads is possible to obtain after 128 days. The cultivar had a consistent growth and size of the heads on the stalk and a high resistance to stress. Cabbage is suitable for use both fresh and for freezing [24]. The experiment was established as randomised blocks with four replications. The effect of distance was investigated as follows:

$-70 \times 50 \mathrm{~cm} ; 0.35 \mathrm{~m}^{2}$ area per plant $(28571$ plants $\times$ ha $^{-1}$ ) - control, distance recommended for species,

$-70 \times 60 \mathrm{~cm} ; 0.42 \mathrm{~m}^{2}$ area per plant $(23809$ plants.ha $\left.{ }^{-1}\right)$,
$-70 \times 70 \mathrm{~cm} ; 0.49 \mathrm{~m}^{2}$ area per plant $(20408$ plants $\times$ ha $^{-1}$ ),

$-70 \times 80 \mathrm{~cm} ; 0.56 \mathrm{~m}^{2}$ area per plant $(17857$ plants $\times$ ha $^{-1}$ ).

The effect of plant density on the growth, development and yield of 'Franklin $F_{1}$ ' Brussels sprouts was analysed. The area of a single plot for harvest was $21.5 \mathrm{~m}^{2}$.

The field experiment was set up after tomato. Following the tomato harvest, postharvest residues and weeds were collected, then potassium and phosphorus fertilizers were applied at the following rates: $75 \mathrm{~kg}$ $\mathrm{K}_{2} \mathrm{O} \times \mathrm{ha}^{-1}$ and $125 \mathrm{~kg} \mathrm{P}_{2} \mathrm{O}_{5} \times \mathrm{ha}^{-1}$. At the end of September, ploughing was performed to a depth of 25-28 $\mathrm{cm}$. In the spring at the end of February, shafting and harrowing was conducted to a depth of 10-12 cm. The planting of seedlings was preceded by an application of nitrogen fertilizer at the rate of $75 \mathrm{~kg} \mathrm{~N} \times \mathrm{ha}^{-1}$.

Brussels sprouts transplants were grown in a non-heated greenhouse. The seeds were sown at the rate of $12-14 \mathrm{~g} \times \mathrm{m}^{-2}$ in $15^{\text {th }}$ of May in seedling containers. Seedling emergence occurred 9-10 days after sowing. Plants in the first-leaf phase (17 days after sowing) were removed and placed in pots $(7 \times 7 \times 7 \mathrm{~cm})$. Prior to transplantation, the plants had five to seven leaves, a short, thick stalk and a well-developed root system.

The transplants were planted in the field 50-51 days following sowing ( $3-4^{\text {th }}$ July). Activities carried out during vegetation period consisted of loosening of the soil surface, weeding, irrigation and protection against diseases and pests.

The leaf area, plant height and stalk diameter were measured when the heads in the axils of the lower leaves reached a marketable size. Leaf area was estimated a direct non-destructive methodology based on linear measurement leaf. The measurement of leaf area relied on measuring the length of the major nerve. On the basis of repeated measurements of length and width of leaf was established the characteristic for cultivar dependence between this parameters and leaf area. On this basis, it made the measuring instrument in the form of ruler allowing for direct reading of the leaf area [25].

Yield harvest was performed once between $25-$ 30 of November and marketable heads $\left(\mathrm{t} \times \mathrm{ha}^{-1}\right)$ had to conform to the requirements within the Ukraine [26].

The results of the experiment were analysed statistically using analysis of variance (ANOVA). The significance of differences was confirmed using Tukey's test at the significance level of $\alpha=0.05$.

On the basis of the long-term mean the optimal thermal conditions for Brussels sprouts growing in the tectonic foreland zone of Crimean Peninsula is from June to October. A moderate reduction in temperature in October favoured head formation. According to long-term data, the amount of precipitation in June 
and July ensures a sufficient water supply for seedlings. However, from August to October, the quantity of rainfall is insufficient to obtain a good quality yield and irrigation is necessary (Fig. 1).
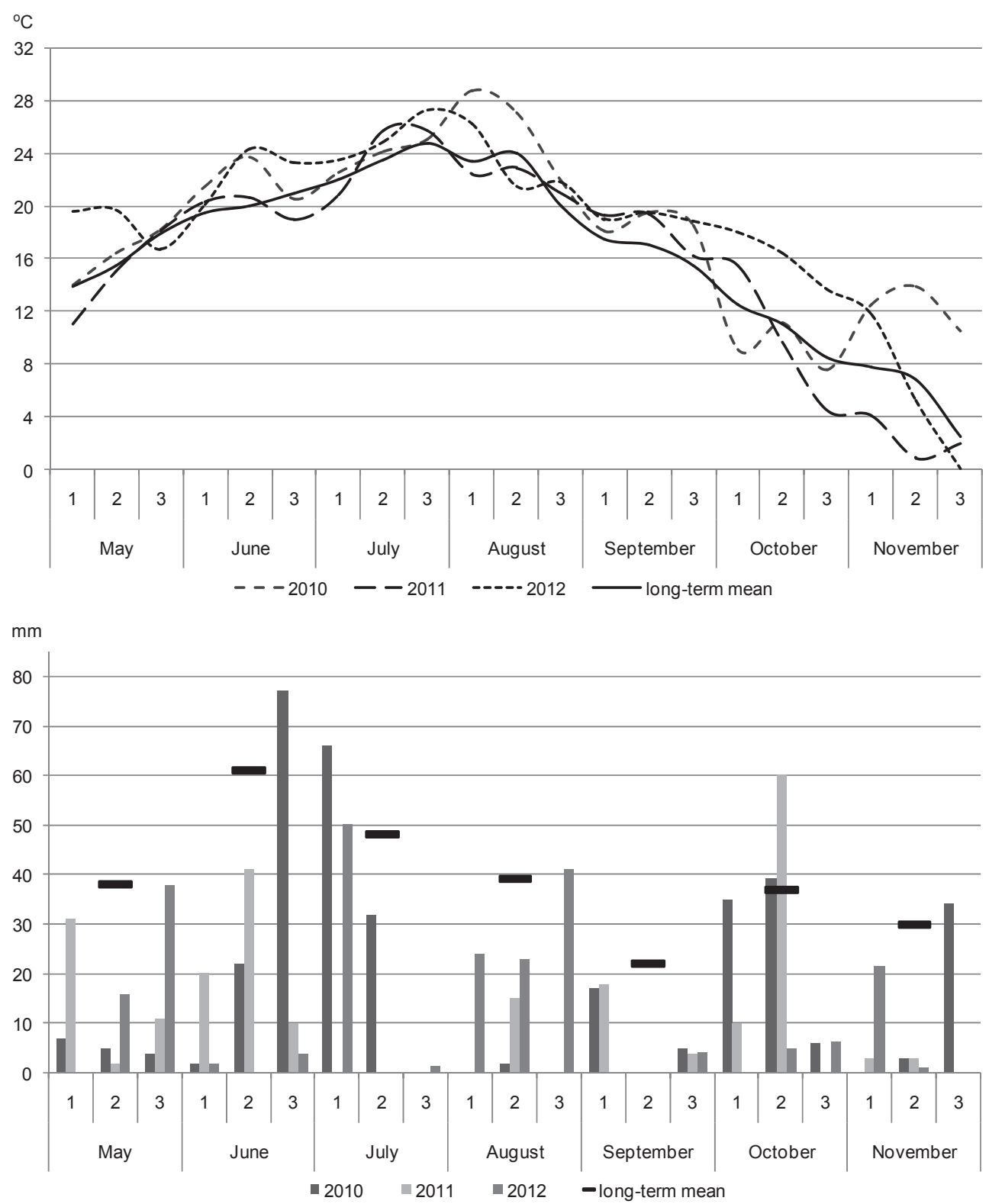

Fig. 1. Mean air temperatures and rainfall during the study

Air temperatures in the study years (20102012) exceeded the long-term mean from the second 10 days of July to the second 10 days of September, except for the third 10-days of August (Fig. 1). For the last 10 days of July and the first and second 10 days of August, temperatures reached maximum values for the growing period. Mean daily temperatures decreased in the last 10 days of August at the start of head formation and had a negative influence on head formation. No rainfall occurred at the end of July and the beginning of August 2010 and 2011, which also had a negative influence on plant growth and head formation.
The yield and yield quality of Brussels sprouts depended on the mean daily temperature in September, October and the first and second 10 days of November. The most favourable influence of thermal conditions on yield was in 2012, when high air temperatures were experienced until the end of the first 10 days of November. In 2010, thermal conditions in October and November were also favourable to obtain a high and good quality yield of Brussels sprouts. In 2011, decreased air temperatures for the second 10 days of October contributed to a reduction yield of heads compared with the other study years. 


\section{RESULTS}

This study shows that a reduction in the area per plant caused an increase in the time taken until the onset of head formation, as well as that to reach technical maturity and harvest (Table 1). The longest time needed to reach these phases was found in control plants with the lowest area per plant $\left(0.35 \mathrm{~m}^{2}\right)$ and the shortest, in plants with the largest area of $0.56 \mathrm{~m}^{2}$.

The mean leaf assimilation area was $25686.8 \mathrm{~cm}^{2}$ in 2010, $17362.0 \mathrm{~cm}^{2}$ in 2011 and $17350.0 \mathrm{~cm}^{2}$ in 2012 , depending on weather conditions (Table 2). The leaf assimilation area of Brussels sprouts ranged from $10998.0 \mathrm{~cm}^{2}$ in 2011 at an area per plant of $0.35 \mathrm{~m}^{2}$ to $31175.1 \mathrm{~cm}^{2}$ in 2010 , at an area per plant of $0.56 \mathrm{~m}^{2}$. In all the study years, assimilation area of leaves increased together with decreasing plant density. In 2012, coefficients lied in critical partition values from 2010 and 2011.

An increased area per plant caused an increase in the stalk diameter, which ranged from $5.5 \mathrm{~cm}$ in 2011 in the control treatment to $10.1 \mathrm{~cm}$ in 2010 for plants with a spacing of $70 \times 80 \mathrm{~cm}$.

Plants cultivated at a low density were shorter than those at a high density, however, the number of heads increased with an increase the area per plant. In the control, the number of heads was the smallest and ranged from 29.5 in 2011 to 46.0 in 2010. The maximum number of heads was obtained for plants with an area of $0.56 \mathrm{~m}^{2}$ and ranged from 39.2 in 2011 to 63.2 in 2010 (Table 2).

The highest marketable yield in all the study years was obtained for a planting of $70 \times 70 \mathrm{~cm}$ and an area per plant of $0.49 \mathrm{~m}^{2}$ (Table 3). The yield was significantly higher compared with that of the other treatments. Although the maximum leaf area and the greatest number of heads were found for plants with an area of $0.56 \mathrm{~m}^{2}$, the highest yield was obtained from plants with an area of $0.49 \mathrm{~m}^{2}$ (Table 2, Table 3). An increased productivity in the third treatment was found, due to a difference in the number of plants within the cultivation area: 17857 plants $\times$ ha $^{-1}$ at $0.56 \mathrm{~m}^{2}$ and 20408 plants $\times$ ha $^{-1}$ at $0.49 \mathrm{~m}^{2}$, respectively.

The greatest number of heads from one plant (44.7 and 45.6), was obtained at an area per plant of 0.49 and $0.56 \mathrm{~m}^{2}$, respectively. The number of marketable heads decreased when plant density was higher (Table 4). A similar dependence of the mean mass of marketable heads on distance was found; at a greater distance, the plants formed larger heads. The area per plant had no significant effect on the length of the stump.

Table 1

Growth and development of Brussels sprouts at different spacing (mean from 2010-2012)

\begin{tabular}{cccc}
\hline \multirow{2}{*}{ Area per plant $\left(\mathrm{m}^{2}\right)$} & \multicolumn{3}{c}{ Number of days from sowing } \\
\cline { 2 - 4 } & Beginning of head formation & Technical maturity & Harvest \\
\hline 0.35 & 115 & 181 & 198 \\
0.42 & 114 & 178 & 197 \\
0.49 & 110 & 177 & 195 \\
0.56 & 108 & 174 & 191 \\
\hline
\end{tabular}

Table 2

Biometric parameters of Brussels sprouts during the harvest in 2010-2012

\begin{tabular}{|c|c|c|c|c|}
\hline Area per plant $\left(\mathrm{m}^{2}\right)$ & Leaf area $\left(\mathrm{cm}^{2}\right)$ & Stalk diameter $(\mathrm{cm})$ & Height of plants $(\mathrm{cm})$ & Number of heads per plant \\
\hline \multicolumn{5}{|c|}{2010} \\
\hline 0.35 & 18908.4 & 8.1 & 92.9 & 46.0 \\
\hline 0.42 & 24910.9 & 8.5 & 83.8 & 55.0 \\
\hline 0.49 & 27752.9 & 9.8 & 78.8 & 62.7 \\
\hline 0.56 & 31175.1 & 10.1 & 71.2 & 63.2 \\
\hline $\mathrm{LSD}_{0.05}$ & 1273.8 & 0.7 & 4.2 & 3.1 \\
\hline \multicolumn{5}{|c|}{2011} \\
\hline 0.35 & 10998.0 & 5.5 & 78.0 & 29.5 \\
\hline 0.42 & 17163.8 & 5.8 & 60.9 & 36.7 \\
\hline 0.49 & 19750.0 & 6.9 & 57.9 & 40.7 \\
\hline 0.56 & 21536.3 & 7.1 & 53.6 & 39.2 \\
\hline $\operatorname{LSD}_{0.05}$ & 692.4 & 0.4 & 2.7 & 2.8 \\
\hline
\end{tabular}




\begin{tabular}{|c|c|c|c|c|}
\hline \multicolumn{5}{|c|}{2012} \\
\hline 0.35 & 14553.9 & 5.6 & 60.9 & 32.5 \\
\hline 0.42 & 16499.7 & 5.8 & 52.4 & 37.6 \\
\hline 0.49 & 17754.0 & 6.4 & 48.4 & 44.2 \\
\hline 0.56 & 20592.4 & 6.5 & 42.6 & 46.4 \\
\hline $\mathrm{LSD}_{0.05}$ & 874.3 & 0.3 & 3.3 & 2.8 \\
\hline \multicolumn{5}{|c|}{ Mean 2010-2012 } \\
\hline 0.35 & 14820.1 & 6.4 & 77.3 & 36.0 \\
\hline 0.42 & 19524.8 & 6.7 & 65.7 & 43.1 \\
\hline 0.49 & 21752.3 & 7.7 & 61.7 & 49.2 \\
\hline 0.56 & 24434.6 & 7.9 & 55.8 & 49.6 \\
\hline
\end{tabular}

Table 3

Yield of marketable $\left(\mathrm{t} \cdot \mathrm{ha}^{-1}\right)$ heads of Brussels sprouts depending on area per plant in 2010-2012

\begin{tabular}{ccccc}
\hline \multirow{2}{*}{$\begin{array}{c}\text { Area per plant } \\
\left(\mathrm{m}^{2}\right)\end{array}$} & 2010 & 2011 & 2012 & Years \\
\cline { 2 - 5 } & 9.6 & 3.5 & 14.0 & 9.0 \\
\hline 0.35 & 11.1 & 7.4 & 14.2 & 10.9 \\
0.42 & 12.3 & 8.8 & 14.6 & 11.9 \\
0.49 & 11.5 & 7.6 & 13.5 & 10.9 \\
0.56 & 0.5 & 0.4 & 0.5 & ns. \\
LSD $_{0.05}$ & & & & \\
\hline
\end{tabular}

ns. - not significant

Table 4

Characteristic of marketable yield of Brussels sprouts (mean from 2010-2012)

\begin{tabular}{ccccc}
\hline $\begin{array}{c}\text { Area per plant } \\
\left(\mathrm{m}^{2}\right)\end{array}$ & $\begin{array}{c}\text { Number of marketable } \\
\text { heads per plant }\end{array}$ & $\begin{array}{c}\text { Mean weight of } \\
\text { marketable heads }(\mathrm{g})\end{array}$ & $\begin{array}{c}\text { Maximal diameter of } \\
\text { marketable heads }(\mathrm{cm})\end{array}$ & $\begin{array}{c}\text { Length of the stump } \\
(\mathrm{cm})\end{array}$ \\
\hline 0.35 & 34.0 & 9.8 & 2.5 & 1.5 \\
0.42 & 38.6 & 12.5 & 2.7 & 1.3 \\
0.49 & 44.7 & 13.2 & 3.0 & 1.5 \\
0.56 & 45.6 & 14.1 & 2.8 & 1.2 \\
$\mathrm{LSD}_{0.05}$ & 2.3 & 1.7 & 0.3 & $\mathrm{~ns}$ \\
\hline
\end{tabular}

ns. - not significant

\section{DISCUSSION}

In the carried studies increased of plants density extended growing period and delayed Brussels sprouts harvest. In the contrary, Evera a r ts et al. [21] did not find any influence of plant density on the number of days to but initiation. Faw us i et al. [27] found that increasing plant density caused a delay in the time to flowering for green peas and maize.

In the investigated range of plants density an increase of area per plant contributed to significant increase of leaf assimilation area, stalk diameter and height of plants. Similar results were obtained by Cresswell and Causton [28] for Brussels sprouts. In this study whole plant, stem, root and foliage, together with specific leaf area, leaf area ratio and number of leaves initiated were reduced by restricting cultivation area. In turn, Abuzeid and $\mathrm{W}$ i $1 \mathrm{c} \mathrm{o} \mathrm{ck} \mathrm{s} \mathrm{on} \mathrm{[12]} \mathrm{was} \mathrm{found} \mathrm{that} \mathrm{increasing} \mathrm{plant}$ density from 2.22 to 6.66 plants $\cdot \mathrm{m}^{-2}$ advanced and increased maximum LAI. However, Mortley et al. [29] found that the stalk diameter increased linearly with an increase in the distance between plants for Amaranthus cultivation. In the study by $\mathrm{N}$ we ke et al. [23] number of branches, number of leaves and vine length decreased as the cucumbers plant spacing increased from $50 \times 30 \mathrm{~cm}$ to $50 \times 40 \mathrm{~cm}$. M i c h a li k and $\mathrm{Szwejkowska}$ [30] showed a higher length 
of leaves and higher individual plant mass of green celery at a lower spacing. S a r k e r et al. [22] was not noted change of cabbage plants height with change of plant density.

An increase of area per plant at a range from 0.35 to $0.49 \mathrm{~m}^{2}$ contributed to increase the marketable yield of Brussels sprouts. Further increase of area per plant caused decrease of yield as a result of lower number of plants on the cultivation area. A similar dependence of producitivity on density was found for Brussels sprouts by Everaarts and De Moel [14], for broccoli by $\mathrm{Bracy}$ et al. [7], who noted an increase in the yield by $36 \%$ with an increase in plant density from 34170 to $64582 \mathrm{ha}^{-1}$. M ich a lik and $\mathrm{Sz} \mathrm{wejk} \mathrm{ow} \mathrm{ska} \mathrm{[30]} \mathrm{observed} \mathrm{a} \mathrm{lower} \mathrm{yield} \mathrm{of}$ green celery at a lower density because of fewer plants in the cultivation area. B e r n s t e n [31] found a higher productivity at a lower plant density by analysing the effect of plant distance in rows spaced 30 and $50 \mathrm{~cm}$ apart (4.5 and 3.0 plants per $\mathrm{m}^{2}$ ) on the yield of Brussels sprouts, however, the yield of sprouts per hectare did not differ significantly. According to B ortne s s [13] low plant density increased the sprouts size, however, did not have influence on the yield of Class 1 sprouts.

Also in the present study was found that increasing of cultivation area per plant caused an increase number of marketable head per plant and an increase mass of marketable head. Similar dependence with respect to number of marketable heads was also found by Everaarts et al. [21], and to mass of heads by Whitwell et al. [16]. According to Abuzeid and Wilcockson [12] increase of plant density increased number of heads per plant growing on the 1 $\mathrm{m}^{2}$, however the size of individual heads decreasing as a result of plants competition by light and reduced production of assimilates. Also in the study by $\mathrm{Gr}$ i f $\mathrm{f} \mathrm{ith}$ and $\mathrm{Carling}$ [32] increase the number of plants from 2.8 to 14.8 per $1 \mathrm{~m}^{2}$ caused linearly decrease the mass and diameter of heads.

Also B i e siada [5] found that a higher plant density had a significant favorable effect on the yield of kohlrabi, but decreased the mean bulb mass. Fi 1 h o et al. [33] found that decreasing the distance between rows from 40 to $30 \mathrm{~cm}$ caused a decrease in the mean mass of lettuce heads from 406.3 to $321.1 \mathrm{~g}$. Furthermore, other studies confirmed that decreasing the area per plant contributed to a higher yield but to a lower mass and diameter of the edible part of plants [3-4, 34-38]. This might be due to a less light reaching the plants [20,39]. Rek ow ska and J u rg a-S zle mp o [6] did not observe a significant effect on the mean mass of endive when the distance between plants in rows changed from 35 to $25 \mathrm{~cm}$.

\section{CONCLUSIONS}

1. Increasing the area per plant resulted in a shortening of the time to the beginning of head formation, technical maturity and harvest.

2. In all the study years, increasing the distance between plants caused an increase in leaf assimilation area, stalk diameter and the number of heads per plant, however, the height of plants was lower.

3. The most favourable parameters characterising marketable yield were found at an area per plant of $0.56 \mathrm{~m}^{2}$, however, the maximum yield from 1 ha was found at an area of $0.49 \mathrm{~m}^{2}$ per plant.

\section{Acknowledgements}

Research funded by the Southern Branch of the National University of Life and Environmental Sciences of Ukraine Crimean Agrotechnological University. The authors would like to acknowledgethe Reviewers and Editors for their valuable comments and suggestions for this paper.

\section{Authors' contributions}

The following declarations about authors' contributions to the research have been made: concept ofthe study: VAT, ASS, field work: VAT, ASS, statistical calculations and writing: VAT, ASS, EK, RR.

\section{REFERENCES}

1. Kurtar ES. The Effect of planting times on some vegatable characters and yield components in Brussels sprouts (Brassica oleracea var. gemmifera). J Agron. 2006; 5(2): 186-190. http://dx.doi.org/10.3923/ja.2006.186.190

2. Dufault RJ, Waters L. Interaction of nitrogen fertility and plant populations on transplanted broccoli and cauliflower yields. Hort Sci. 1985; 20(1): 127-128.

3. Wlazło A, Kunicki E, Libik A. Wpływ metody uprawy i zagęszczenia roślin na wielkość i jakość plonu brokułu. Folia Hort. 2006; Supl. 2: 197-202.

4. Schellenberg DL, Bratsch AD, Shen Z. Large single-head broccoli yield as affected by plant density, nitrogen, and cultivar in a plasticulture system. Hort Technology 2009; 19: 792-795.

5. Biesiada A. Effect of flat covers and plant density on yielding and quality of kohlrabi. J Elementol. 2008; 13(2): 167-173.

6. Rekowska E, Jurga-Szlempo B. Influence of growing date and plant density on the yield of endive (Cichorium endivia L.). Acta Sci Pol, Hortorum Cultus. 2011; 10(1): 13-21.

7. Bracy RP, Parish RL, Mulkey WA. High-density planting in a precision cultural system for vegetable production. Hort Tech. 1991; 1(1): 54-58. 
8. Ozer H. The effect of plant population densities on growth, yield and yield components of two spring rapeseed cultivars. Plant Soil Environ. 2003; 49(9): 422-426.

9. Diepe nbrock W. Yield analysis of winter oilseed rape (Brassicanapus L.): a review. Field Crops Res. 2000; 67(1): 35-49. http://dx.doi.org/10.1016/S0378-4290(00)00082-4

10. Orłowski M, Kołota E. Uprawa warzyw. Szczecin: Brasika; 1993. p. 24-27.

11. Dobromilska R. Kapusta brukselska. (w:) Orłowski M. Polowa uprawa warzyw. Szczecin: Brasika; 2000. p. 31-37.

12. Abuzeid AE, Wilcockson SJ. Effects of sowing date, plant density and year on growth and yield of Brussels sprouts (Brassica oleracea var. bullata subvar. gemmifera). J Agric Sci. 1989; 112(03): 359-375. http://dx.doi. org/10.1017/S0021859600085816

13. B ortness G. The effects of planting date, plant density and stopping on three cultivars of Brussels sprouts. NorskLandbruksforsking 1990; 4: 155-159.

14. Everaarts AP, De Moel CP. Effects of planting time and plant density on growth, development, yield and grading of Brussels sprouts (Brassica oleracea var. gemmifera). J HorticSciBiotechnol. 1998; 73(4): 549-554.

15. Lan Chow Wing K.F. Rajkomar I. Selection and planting density of early-yielding leaf vegetables and the 'consumption index'. Acta Hort. 1985; 153: 127-134.

16. Whitwell JD, Senior D, Morris GEL. Effects of variety, plant density, stopping time and harvest date on drilled Brussels sprouts for processing. Acta Hort. 1981; 122: 151-166.

17. Mulkey WA, Porter WC. Maximizing cabbage yields and packout in northeast Louisiana. Louisiana Agr. 1987; 31(1): 16-17.

18. Islam AF, Islam MS, Farooque AM, Islam MN. Effect of age of seedling and spacing on the performance of cabbage. Bangladesh Hort. 1989; 15 (2): 1-6.

19. Farooque AM, Mondal MF. Effect of spacing and levels of nitrogen on growth and yield of cabbage. Bangladesh Hort. 1987; 15(2): 1-6.

20. Mon ir u z z a man M. Effect of plant spacings on the performance of hybrid cabbage (Brassica oleracea var. capitata) varieties. Bangladesh J Agril Res. 36(3); 2011: 495-506. http://dx.doi.org/10.3329/bjar.v36i3.9277

21. Everaarts AP, Booji R, De Moel CP. Yield formation in Brussels sprouts. J HorticSciBiotechnol. 1998; 73(5): 711-721.

22. Sarker MY, Azad AK, Hasan MK, Nasreen A, Naher Q, Baset MA. Effect of Plant Spacing and Sources of Nutrients on the Growth and Yield of Cabbage. Pakistan J Biol Sci. 2002; 5(6): 636-639. http://dx.doi. org/10.3923/pjbs.2002.636.639

23. Nweke IA, Orji EC, Ijearu SI. The effect of staking and plant spacing on the growth and yield of cucumber (Cucumis sativus L.). J Environ Sci Tox Food Technol. (IOSR-JESTFT). 2013; 3(4): 26-31. http://dx.doi. org/10.9790/2402-0342631
24. http://www.bejo.ua/ua/асортимент/асортимент/гібрид. aspx ?ProductID=PROD12206\&GroupID=SHOP22_162 (dostęp 2.12.2014)

25. Blanco FF, Folegatti MV. A new method for estimating the leaf area index of cucumber and tomato plants. Hortic Bras. 2003; 21(4): 666-669. http://dx.doi. org/10.1590/S0102-05362003000400019

26. Derzhavni Standarty Ukrayiny (ДСТУ) 1915-91. Kapusta bryussel'skaya svezhaya. Tekhnicheskiye usloviya. p. 10

27. Fawusi MOA, Wanki SBC, Nangju D. Plant density effects on growth, yield, leaf area index and light transmission on intercropped maize and Vignaunguiculata (L.) Walp. in Nigeria. J Agr Sci. 1982; 99(1): 19-23. http:// dx.doi.org/10.1017/ S0021859600054988

28. Cresswell A, Causton DR. The effect of rooting space on whole plant and leaf growth in Brussels sprouts (Brassica oleracea var. gemmifera). Ann Bot. 1988; 62(5): 549-558.

29. Mortley DG, Rhoden EG, Khan VA. Plant spacing influences yield of vegetable amaranth. Acta Hort. 1992; 318: 217-224.

30. Michalik Ł, Szwejkowska B. Wpływ metody uprawy i gęstości sadzenia rozsady na wielkość plonu selera naciowego. Zesz. Nauk. AR Wroc. 2005; Rol. LXXXVI 515: 353-358.

31. Bernsten R. Growing techniques for Brussels sprout. Acta Agr Scand. 1975; 25(1): 25-29.http://dx.doi.org/10. 1080/00015127509435031

32. Griffith M, Carling DE. Effects of plant spacing on broccoli yield and hollow stem in Alaska. Can J Plant Sci. 1991; 71(2): 579-585. http://dx.doi.org/10.4141/cjps91-087

33. Filho AB, Rezende BLA, Canato GHD. Lettuce and radish productivity in intercropping systems as influenced by starting time and spacings. Hortic Bras. 2007; 25(1): 15-19. http://dx.doi.org/10.1590/S0102-053 62007000100004

34. Kunicki E, Capecka E, Siwek P, Kalisz A. The effect of plant spacing on the yield and quality of three broccoli cultivar in autumn growing. Folia Hort. 1999; 11/2: 69-79.

35. Rekowska E. Studia nad doskonaleniem technologii uprawy brokułu w rejonie Pomorza Zachodniego. Zesz. Nauk. AR Szczecin. 2002; Ser. Rozpr. 211.

36. Dobromilska R. The effect of growing method and plant spacing on the fennel yielding in unheated greenhouse. Zesz. Nauk. AR Wroc., 2005; Rol. LXXXVI 515: 103-109.

37. Moravčević D, Bjelić V, Vućković S. Effects of crop density on fodder yield in cabbage production. Biotechnol Anim Husb. 2005; 21(5-6): 159-162. http://dx.doi. org/10.2298/ bah0502159m

38. El-Hamed K, Elwan M. Dependence of pumpkin yield on plant density and variety. Am J Plant Sci. 2011; 2(5): 636-643. http://dx.doi.org./10.4236/ajps.2011.25075

39. D obromils k a R. Effect of growing place on growth and development of two fennel cultivars. Part I. Biometric properties of plants. Umbell Improv Newsl. 2000; 10: 30-32. 


\section{Wpływ zagęszczenia roślin na wzrost, rozwój i plonowanie kapusty brukselskiej (Brassica oleracea L. var. gemmifera L.)}

\section{Streszczenie}

Gęstość sadzenia roślin jest ważną zmienną w uzyskiwaniu maksymalnego plonu i jednakowej dojrzałości warzyw. Optymalne zagęszczenie roślin można uzyskać poprzez ustalenie właściwych odległości zarówno w rzędzie jak i pomiędzy rzędami roślin. Doświadczenie prowadzono w latach 2010-2012 na polu doświadczalnym Katedry Warzywnictwa i Standaryzacji Krymskiego Uniwersytetu Agrotechnologicznego w Symferopolu. Doświadczenie założono metodą losowanych bloków w czterech powtórzeniach. Celem badań było określenie wpływu powierzchni przypadającej na jedną roślinę przy różnej rozstawie na wzrost, rozwój i plonowanie kapusty brukselskiej. Wraz ze zwiększaniem powierzchni przypadającej na 1 roślinę skróceniu ulegał okres od wysiewu nasion do począt$\mathrm{ku}$ formowania główek oraz do osiągnięcia dojrzałości technologicznej i zbioru plonu. We wszystkich latach badań w miarę zwiększania rozstawy wzrastała powierzchnia asymilacyjna liści, średnica łodygi oraz liczba główek na roślinie, natomiast malała wysokość roślin. Najkorzystniejsze parametry charakteryzujące plon handlowy stwierdzono przy powierzchni przypadającej na roślinę wynoszącej $0,56 \mathrm{~m}^{2}$, natomiast maksymalny plon z jednego hektara (decydujący o opłacalności uprawy) przy powierzchni $0,49 \mathrm{~m}^{2}$.

Handling Editor: Elżbieta Weryszko-Chmielewska

This is an Open Access digital version of the article distributed under the terms of the Creative Commons Attribution 3.0 License (creativecommons.org/licenses/by/3.0/), which permits redistribution, commercial and non-commercial, provided that the article is properly cited. 